Article

\title{
Senior Housing Universal Design as a Development Factor of Sustainable-Oriented Economy
}

\author{
Krzysztof Malik ${ }^{1, *(\mathbb{D})}$ and Ewa Mikołajczak ${ }^{2}$ \\ 1 Department of Economics, Finance and Regional Research, Faculty of Economics and Management, \\ The Opole University of Technology, Prószkowska 76, 45-758 Opole, Poland \\ 2 Jung Architekten, Große Venedig 31, 31134 Hildesheim, Germany; e.mikolajczak@architekten-jung.de \\ * Correspondence: k.malik@po.edu.pl; Tel.: +48-600-96-11-61
}

Received: 22 November 2019; Accepted: 9 December 2019; Published: 11 December 2019

\begin{abstract}
Elderly and disabled individuals constitute over $25 \%$ of the population with a perspective of reaching $35 \%$ in 2040. This trend triggers the dynamic development of the silver economy, which aims to satisfy the needs specific to this social group. One of the cornerstones of that sector concerns appropriate housing, which — as for now-is often maladapted, making daily activities highly demanding. This problem should be addressed in a systematic and sustainable manner. A current solution is to adjust the existing flats, which is suboptimal, due to high costs and technical limitations that in many cases, cannot be overcome. The purpose of this study was to demonstrate that a primary design of living spaces suitable for senior citizens (barrier-free flats) is more beneficial from the socio-economic perspective as compared to the adaptation of existing houses. We analyzed the economic and social costs/benefits of the contemporarily available flat adjustment strategies and the primary design of barrier-free houses. We found that the implementation of standardized design principles at the stage of architectural design can reduce yearly costs of the national economy by $\sim$ PLN 385 billion (> 19\% of Poland's GDP), making the universal design senior housing an efficient response to the arising requirements of our aging society.
\end{abstract}

Keywords: sustainable development; senior housing; universal design; comparative cost-benefit analysis

\section{Introduction}

In recent years, we have seen a significant improvement in the housing offer addressing the elderly. The proposed spectrum of housing solutions is expanding in accordance with customers' expectations, offering, among others, the adaptation of flats to make them meet the needs of the elderly. As a result, "aging at home" is acquiring entirely new significance than several years ago.

If a given elderly person is particularly strongly connected to their current dwelling, the offer referred to as "aging in place" is often the best solution. The term "aging in place" assumes the lack of necessity to change one's place of residence. Its adaptation to facilitate the everyday functioning could provide the desired sense of safety and social stability. It requires, however, a specialist preparation-both sociological and architectural.

Considering the progressive aging of the population, providing the elderly with the possibility of living in appropriate conditions satisfying their expectations is becoming an obligation of society. Regrettably, the significant majority of existing flats is not elderly-friendly; their technical maladaptation makes daily functioning difficult or even impossible. In some cases, elderly people, particularly those suffering from certain physical disabilities, are confined to their homes and become "prisoners of the four walls". A current solution to this problem involves the adaptation of flats to satisfy the needs of the elderly, which, however, is often unaffordable or technically impossible. 
The "design for all" concept has been considered as a key strategy for creating social inclusion. Some research have undertaken the problem of universal design contribution to sustainable development from the point of the city space and/or urban design only [1,2].

The universal design of senior housing (UDSH) is relatively new, and uprising approach to primarily construct flats that would meet the needs of the elderly and/or disabled ones. These have been termed "barrier-free flats". The necessary adaptations are implemented at the architectural design stage and involve modifications of bathroom, kitchen, household equipment, furniture, doors, as well as passageways.

The relevance of the problem undertaken is justified by the existing gap between poor demand for universal design senior housing, UDSH (which is relatively cheap) and crucial socio-economic benefits from this kind of construction. The reason for the gap is a market failure in assessing values in a different time. The cost of UDSH (in present young generation value) cannot be compared to the older people benefits (measured in terms of future generation values). In inter-generations calculations (over 25 years), the traditional discounting is no longer adequate [3].

This market failure results from one side—-the poor demand for building (new) housing, which has been designed to house older population (relatively cheap) and from the other side- the demand for age-friendly house renovations (relatively expensive) acceding the supply of such renovation [4].

From the perspective of society as a whole (which combines of both young and old generations), is it relevant to investigate the social and economic benefits of fixing the market failure which is recognized as an important driver of development- the silver industry.

Supporting the senior housing (as an important element of the silver industry) fits into the concept and policy of sustainable development and promotes its implementation into the economy. The purpose of the undertaken study was to demonstrate that the primary design of senior citizens' living space in the form of barrier-free flats is-in the long run-justified by economic and social benefits as compared to secondary reconstructions and adaptations of existing apartments.

\section{Materials and Methods}

\subsection{Primary Elements of Barrier-Free Senior Housing}

The barrier-free flats are newly built flats adapted for elderly and/or disabled individuals, where all architectural barriers have been removed at the initial design phase. In order to ensure comfortable daily functioning of the target social group, the barrier-free design should be considered when designing new flats in multi-family housing.

Important principles of barrier-free design include [5]:

- equitable use-solutions should be useful and attractive for persons characterized by varied physical ability; designs should include all types of residents as a temporary disability is independent of age;

- flexibility in use- each solution should take into consideration needs and possibilities of various users without restrictions;

- $\quad$ simple and intuitive-all solutions should be easy to understand;

- perceptible information-regardless of user's sensory abilities;

- tolerance for error-minimization of the misuse of a given product;

- low physical effort—use should not be tiring; tiredness (if any) should be minimized;

- $\quad$ size and space for approach and use-solutions addressing everybody, regardless of their body build and size.

Important elements of universal design include the following:

- bathroom—safe bath (providing adequate space enabling necessary maneuverability, railings, holders/grips, height of bathroom furniture, adjusted shower, special toilet seats etc.); 
- comfortable kitchen - the room, where particular attention should be paid to functionality and safety; appropriately fixed cupboards and kitchen equipment; access to equipment and furniture should be ergonomic and comfortable;

- doors and doorsteps-appropriate widths of doorways, heights at which handles are fixed, automatic door opening assistance etc.;

- windows, balconies, terraces-situated at appropriate heights, use of automatic opening mechanisms, doorstep-free balconies/terraces, adjusted railing and adequate space enabling necessary maneuverability;

- access to buildings-floors, ramps and navigation systems should address the needs of any potential user, regardless of their physical form.

The universal design senior housing includes the ergonomic characteristics of the internal living space in order to enable older persons to stay free and active within their life course.

\subsection{Comparative Cost-Benefit Analysis}

The methodology undertaken in the research is based on cost-benefit analyses (CBA) used to compare the two alternative projects of fulfilling the living needs of senior people. The first solution is to adjust the existing flats in order to make them meet the needs of the elderly. The alternative is to introduce primary design of living spaces suitable for senior citizens (barrier-free flats). This alternative kind of approach is being called the universal design senior housing (UDSH). We assumed the sustainability paradigm in order to analyze the silver industry impact into the economy development.

The purpose of analyzes was to demonstrate that a UDSH is more beneficial from the sustainable development perspective as compared to the adaptation of existing houses. To provide the cost-benefit analyzes and assessment, based on the sustainability paradigm, we identified the important elements of CBA by investigating impact of the silver impact on the sustainability of development capital of the Polish economy example (Table 5).

The endpoint of the study was to demonstrate the cost-effectiveness of the primary building of the flats specifically designed to accommodate the needs of both the elderly and disabled individuals (barrier-free flats or UDSH). When calculating the construction cost of the UDSH, more than 100 variables were considered and analyzed within seven main categories: Ground costs, costs of preparing and connecting the area, construction costs, costs of technical devices installation, costs of external devices, costs of equipment, and other associated costs (Table 2). We identified the variables whose cost would change when constructing a UDSH flat.

The obtained data were subsequently compared with the costs associated with the adaptation of an existing flat to accommodate the needs of the elderly/ disabled individuals. The same construction variables were taken into consideration. All the calculations were based on the author's research conducted in Opole, Warsaw and Berlin senior housing estate on the prices scheme depicted in the catalogues of material expenditure (KNR). The comparative analysis was based on the data from the Polish Statistical Office.

\section{Results}

The verifications were provided from the point of measurable social and economic costs and benefits (Tables 1-4). We provided the research based on the Polish statistics data and costs calculated on the base of the Polish Catalogues of Material Expenditures. The adaptation of an already existing flat to meet the needs of an elderly person entails high costs, as shown in many studies and analyses. Presented below (Table 1) are the main outcomes of analyses of costs resulting from the adjustment, adaptation and the reconstruction of existing buildings and flats based on the current market prices [6]:

- Movement sensors-approximately 850 PLN

- Adjustment of lighting illuminating the access to buildings-approximately 2600 PLN

- Rebuilding/ building a ramp providing access to the building - approximately 12,000 PLN

- Widening of doorways, including doors (3-4 items) - approximately 12,000 PLN 
- Changes of switches-approximately 1700 PLN

- Adaptation of heights at which electric sockets are installed and the redesign/change of the wiring system (if necessary)—approximately 4700 PLN

- New flooring (3-4 rooms)-approximately 8550 PLN

Total adaptation costs equal to 42,400 PLN.

Average price of a 50 sq. $\mathrm{m}$ apartment in Poland (2017) was 221,000 PLN, so the average costs of adaptation existing flat accounted for $19.2 \%$ of the flat value (Table 1 ).

Table 1. Comparative economic cost-benefit analysis with values from the year 2017.

\begin{tabular}{|c|c|c|c|c|}
\hline \multicolumn{2}{|c|}{ Cost of Adaptation of Existing Flats } & \multicolumn{3}{|c|}{ Cost of Initially Universal Designing Flat Constructing } \\
\hline & \\
\hline & & \multicolumn{2}{|c|}{ As in Table 2} & Price of average 50 sq. $\mathrm{m}$ flat $=221,200$ PLN \\
\hline \multicolumn{5}{|c|}{ Adaptation cost of the flat (total) $=42,400$ PLN } \\
\hline \multicolumn{2}{|c|}{ Cost of adaptation as $\%$ of the flat value $=19.2 \%$} & \multicolumn{2}{|c|}{$1.24 \%$} & \\
\hline \multicolumn{5}{|c|}{ Economic benefits as $\%$ of cost decreasing $17.96 \%$} \\
\hline \multicolumn{5}{|c|}{ Economic benefits as the value of cost decreasing per 1 sq. $\mathrm{m} .=795$ PLN for $1 \mathrm{sq} . \mathrm{m}$} \\
\hline \multicolumn{5}{|c|}{ Economic benefits as the value of cost decreasing per average 50 sq. meter flat $=39,750$ PLN } \\
\hline \multicolumn{5}{|c|}{ Housing resources in Poland in sq. $\mathrm{m}=1068.6$ million sq. $\mathrm{m}$} \\
\hline \multicolumn{5}{|c|}{ The number of seniors $(60+)$ and people with disabilities $=25.9 \%$ of the population in 2018.} \\
\hline \multicolumn{5}{|c|}{ Resources of housing inhabited by seniors and people with disabilities $=276.77$ million sq. $\mathrm{m}$} \\
\hline \multicolumn{5}{|c|}{$\begin{array}{l}\text { Opportunity costs of not applying universal designing ahead }=220,030 \mathrm{mln} \text {. PLN } \\
\text { Opportunity costs of not applying universal designing ahead as } \% \text { of } 2017 \mathrm{GDP}=11.06 \%\end{array}$} \\
\hline \multicolumn{5}{|c|}{$\begin{array}{l}\text { Subsequently, the cost of building the barrier-free flats has been estimated using the National } \\
\text { Contractor's Estimation for multi-family residential buildings in Opole and Warsaw in } 2017 \\
\text { The analysis concerns the as-built-by-developer state. Furniture has not been subjected to analysis } \\
\text { (Table 2). }\end{array}$} \\
\hline $\begin{array}{l}\text { DIN } 276 \text { Investment Costs } \\
\text { Specification }\end{array}$ & $\begin{array}{l}\text { Estimated Share of the Groups } \\
\text { in the Total Costs and Selected } \\
\text { Calculation Items in the Groups }\end{array}$ & $\begin{array}{l}\text { The weight of the } \\
\text { Increase in Total Costs } \\
\text { for Individual Groups }\end{array}$ & $\begin{array}{l}\text { Estimated } \\
\text { Cost } \\
\text { Increase }\end{array}$ & $\begin{array}{l}\text { Change in } \\
\text { Share of Total } \\
\text { Costs }\end{array}$ \\
\hline 100. GROUND COSTS & $15.0 \%$ & $0 \%$ & & $0.0 \%$ \\
\hline $\begin{array}{l}\text { 200. COSTS OF PREPARING } \\
\text { AND CONNECTING THE AREA }\end{array}$ & $1.5 \%$ & $0 \%$ & & $0.0 \%$ \\
\hline $\begin{array}{l}\text { 300. CONSTRUCTION COSTS, } \\
\text { incl.: }\end{array}$ & $53 \%, \mathrm{w}$ tym & & & $0.5 \%$ \\
\hline $\begin{array}{l}\text { Walls in corridors and } \\
\text { bathroom, interior walls; }\end{array}$ & $10 \%$ KG300 & $5.3 \%$ & $6 \%$ & $0.06 \%$ \\
\hline $\begin{array}{l}\text { External woodwork, doors, } \\
\text { windows }\end{array}$ & $2.3 \%$ KG300 & $1.2 \%$ & $10 \%$ & $0.01 \%$ \\
\hline $\begin{array}{l}\text { Flooring, tactical systems, } \\
\text { contrast, signs }\end{array}$ & $1.6 \%$ KG300 & $0.85 \%$ & $10 \%$ & $0.09 \%$ \\
\hline $\begin{array}{l}\text { Railings, bumpers and } \\
\text { handrails, shutters, awnings and } \\
\text { blinds, including drivers }\end{array}$ & $0.53 \%$ & $0.27 \%$ & $50 \%$ & $\begin{array}{l}0.13 \\
0.21\end{array}$ \\
\hline $\begin{array}{l}\text { 400. INSTALLATION COSTS OF } \\
\text { TECHNICAL DEVICES }\end{array}$ & $17 \%$ & $2 \%$ & & 0.34 \\
\hline $\begin{array}{l}\text { 500. COSTS OF EXTERNAL } \\
\text { DEVICES }\end{array}$ & $1.50 \%$ & $4 \%$ & & $0.10 \%$ \\
\hline
\end{tabular}


Table 2. Cont.

\begin{tabular}{|c|c|c|c|c|}
\hline $\begin{array}{l}\text { DIN } 276 \text { Investment Costs } \\
\text { Specification }\end{array}$ & $\begin{array}{l}\text { Estimated Share of the Groups } \\
\text { in the Total Costs and Selected } \\
\text { Calculation Items in the Groups }\end{array}$ & $\begin{array}{l}\text { The weight of the } \\
\text { Increase in Total Costs } \\
\text { for Individual Groups }\end{array}$ & $\begin{array}{l}\text { Estimated } \\
\text { Cost } \\
\text { Increase }\end{array}$ & $\begin{array}{l}\text { Change in } \\
\text { Share of Total } \\
\text { Costs }\end{array}$ \\
\hline $\begin{array}{l}\text { 600. EQUIPMENT COSTS AND } \\
\text { WORKS OF ART }\end{array}$ & $5 \%$ & $5 \%$ & $100 \%$ & $0.30 \%$ \\
\hline 700. ASSOCIATED COSTS & $7 \%$ & $0 \%$ & & $0.0 \%$ \\
\hline Total costs & $100.0 \%$ & & & $1.24 \%$ \\
\hline \multicolumn{5}{|c|}{$\begin{array}{l}\text { Source: Results of our own calculations based on prices of universal design of senior estates in Opole, Warsaw } \\
\text { and Berlin verified by Catalogues of Material Expenditure: Katalogi Nakładów Rzeczowych, (KNR): KNR 2-02: } \\
\text { Structures, Chap. } 10 \text { Woodwork, KNR 4-01, Chap. 09 Carpentry works, KNR 5-08: Light installations and } \\
\text { equipment, KNR 4-01: Construction renovation works, KNR 4-02: Installation repair works, KNR 4-04: Demolition } \\
\text { works for buildings, KNR 2-15u2, Publisher: Wydawnictwo Budowlane Koprin, 2017 [10]; Internal sanitary } \\
\text { installations: BKI Baukosten Gebäude + Bauelemente + Positionen Neubau 2017-Kombi Teil 1-3: Statistische } \\
\text { Kostenkennwerte Gebäude, Positionen und Bauelemente Taschenbuch, BKI Baukosteninformationszentrum, 2017I, } \\
\text { SBN-10: 348103637X, ISBN-13: 978-3481036379 [11]. }\end{array}$} \\
\hline
\end{tabular}

The above-presented analysis demonstrates that the barrier-free flat in the as-built-by-the-developer state increases the entire costs of construction by $1.24 \%$ as compared to the standards of currently built flats in multi-family residential buildings. Over 100 single items divided into seven main categories (Table 2) have been considered in the analysis, and most of them do not entail additional costs when constructing a barrier-free flat.

Our results are compatible with a similar study that has been conducted to calculate the reconstruction cost of 52 sq. $m$ flat located in Warsaw (Poland) in 2016 [12]. The Terragon Analysis involved 148 elements and demonstrated that the difference between the costs incurred during the construction of barrier-free buildings is restricted within the range of $0.54 \%$ to $1.26 \%$, depending on the level of adaptation [13].

For comparison, the costs of adaption of an existing standard apartment to the costs of construction of an apartment adapted for the elderly or disabled (barrier-free flats) are much higher-up to $19.2 \%$ of the flat value. By introducing the universal design principles in the initial stages of the project, additional reconstruction costs of existing flats can be reduced from $19.2 \%$ to $1.24 \%$.

The extra cost of initially universal designing UDSH flat constructing has been calculated as $1.24 \%$ total costs increase. The cost of adaptation as $\%$ of the flat value equals to $19.2 \%$ of total costs value. It means that by introducing UDSH approach, one could save $17.96 \%$ of total individual costs. In order to calculate the social-economic costs and benefits from the perspective of the Polish economy, we developed the list of social-economic costs/benefits as (Tables 3 and 4):

For comparability, all costs elements have been calculated as the percent of GDP (Poland, 2017). By implementing the appropriate universal design principles at the architectural design stage (UDSH), we can reduce the social and economic costs by approx. PLN 385 billion, which corresponds to more than 19\% of Poland's GDP (at 2017 prices).

We develop the list of economic and social cost/benefits assigned to UDSH (Tables 3 and 4).

The calculated social and economic costs are indeed external costs to the economy. The externalities, which generates market failure in optimal resource allocation requires public policy intervention. While implementing the UDSH approach into the economy-the macro social and economic benefits would appear (as in the table below).

From the perspective of society as a whole (which combines of both young and old generations), is it relevant to investigate the social and economic benefits of fixing the market failure which is recognized as an important driver of development-the silver industry. The external economic benefits equal to $19.36 \%$ of Polish GDP. The macro social and economic benefits must be reduced by the costs of internalizing the macro benefits into the microeconomic calculation of construction enterprises.

If we implement the appropriate universal design principles at the architectural design stage, we can reduce costs by approx. PLN 385 billion, which corresponds to more than $19 \%$ of Poland's GDP (at 2017 prices). Bearing in mind the CSO forecasts, where, in 2040 seniors will already constitute about $35 \%$ of the population, universal design can provide Poland with even higher economic and social benefits. 
The criteria of selection of the costs/benefits have been analyzed according to the elements (capitals) of the sustainable development paradigm and silver industry characteristics. However, the methodology of identifying the cost/benefit elements should be developed from one hand, but from the other-it is limited by data availability.

Table 3. Cost-benefit analyses of UDSH implementing: Social and economic costs.

\begin{tabular}{|c|c|c|}
\hline Social and Economic Costs & Values & $\begin{array}{l}\text { Calculated as the Percent of GDP } \\
\text { (Poland, 2017) }\end{array}$ \\
\hline (1) opportunity costs of not applying $\mathrm{UDSH}^{1}$ & 220,030 mln PLN & 11.06 \\
\hline (2) public costs of subsiding retirement houses ${ }^{2}$ & $1000 \mathrm{mln}$ PLN & 0.05 \\
\hline $\begin{array}{l}\text { (3) costs of decreasing the purchasing power of the older } \\
\text { population (while not attending in social life) }\end{array}$ & $164,118 \mathrm{mln}$ PLN & $\begin{array}{l}\text { Purchasing power to housing } \\
\text { maintenance }=33 \% \mathrm{GDP} \text { and } 25 \% \text { older } \\
\text { people share in the population }=8.25\end{array}$ \\
\hline \multicolumn{3}{|l|}{ (4) Immeasurable human and social costs of: } \\
\hline \multicolumn{3}{|l|}{ a inequalities in wellbeing and independent living } \\
\hline $\begin{array}{l}\text { b decreasing opportunities for individualization and level of } \\
\text { public space access stimulation }{ }^{4}\end{array}$ & & \multirow[t]{2}{*}{$(+)$} \\
\hline \multicolumn{2}{|l|}{$\begin{array}{l}\mathrm{c} \text { being passive place makers, do not creating their social and } \\
\text { care networks } 5\end{array}$} & \\
\hline All together costs & $385,148 \mathrm{mln}$ PLN & 19.36 \\
\hline \multicolumn{3}{|c|}{$\begin{array}{l}{ }^{1} \text { See Table } 1 .{ }^{2} \text { Opieka dla seniora } 2018 \text { (Senior people care 2018). Available online: https://polskatimes.pl/opieka-dla- } \\
\text { seniora-2018-ile-to-kosztuje-jak-zalatwic-pobyt/ar/13239805 (accessed on } 29 \text { November 2019), [14]. }{ }^{3} \text { Eurostat Household } \\
\text { Budget Survey [15]. }{ }^{4} \text { Barrett, P., L. Barrett and F. Davies 2013. Achieving a step change in the optimal sensory design } \\
\text { of buildings for users at all life-stages. Building and Environment, 67, 97-104 [16]. }{ }^{5} \text { Peine, A., I. Rollwagen and L. } \\
\text { Neven 2014. The rise of the "innosumer"-Rethinking older technology users. Technological Forecasting and Social } \\
\text { Change, 82, 199-214, [17]. Source: Own calculation. }\end{array}$} \\
\hline
\end{tabular}

Table 4. Cost-benefit analyses of UDSH implementing: Social and economic benefits.

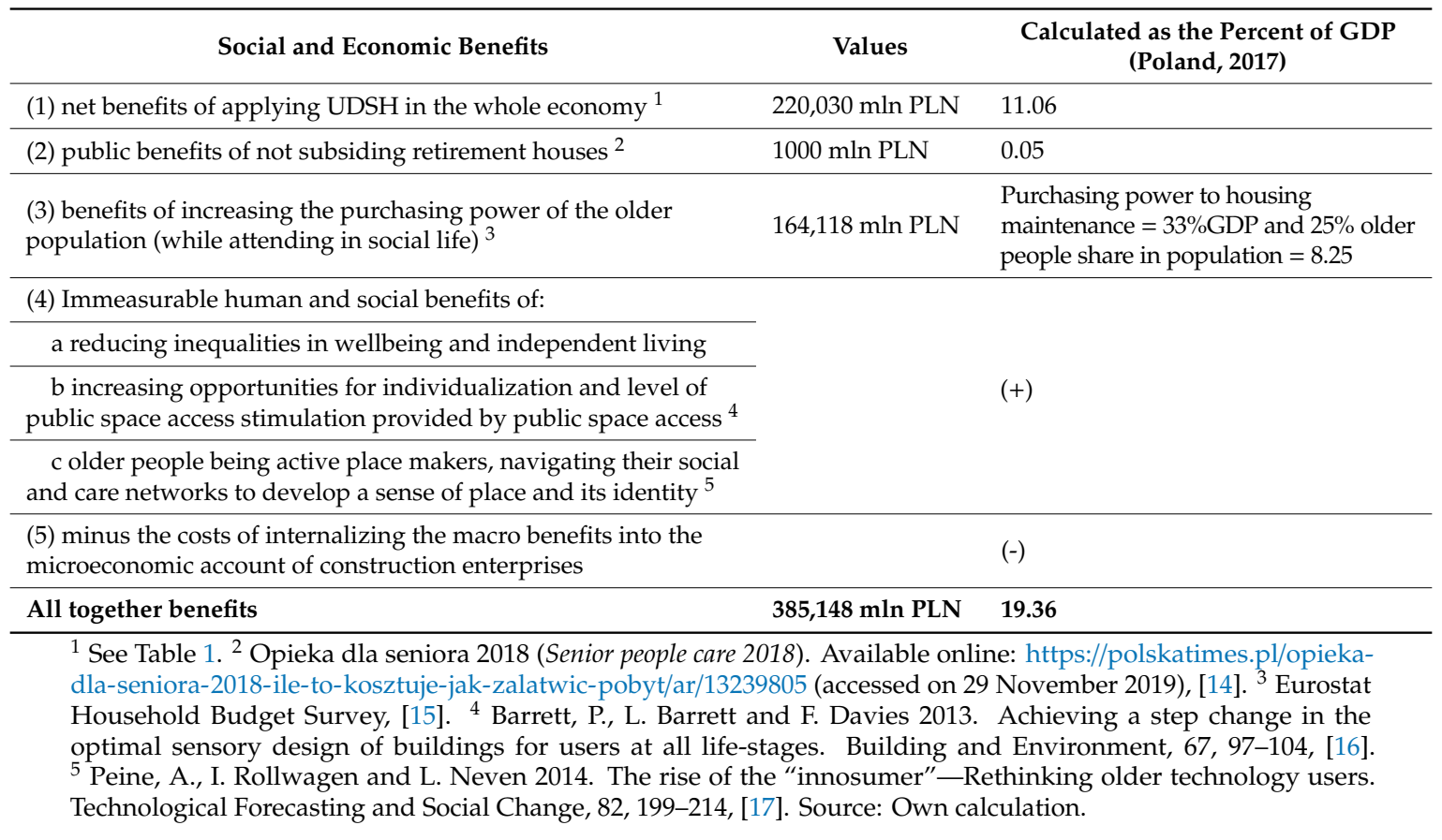

\section{Discussion}

\subsection{Aging and Health Conditioning of Senior Housing}

Data published by the Central Statistical Office of Poland revealed that over the past 25 years there had been a deceleration of demographic development followed by considerable changes in the age structure of Polish citizens. Extended life expectancy resulting from medical progress and a low total 
fertility rate are the reasons behind the aging of the population. At the same time, these demographic changes have been intensified by an increased emigration of young people [18].

Further studies by the Polish Central Statistical Office and the Department for Demographic and Labour Market Research revealed that in 2050 the mean age would increase up to 48.8 years and 53.7 years for men and women, respectively, i.e., by 10.9 and 12.3 years. The rate of aging will vary, i.e., until 2020, the average age would increase by 2.3 years (by 2.2 for men and 2.3 for women). Within the next 20 years, until 2040, the mean age will grow significantly, i.e., by 7.3 years (by 7.0 for men and 7.6 for women) [19].

For the needs of international statistics, the new category of the population has been developed and termed "a residing population". It stands for the total number of persons residing/staying in a given territory for a minimum of 12 months. At the end of 2017, the Polish population stood at 38.4 million, with over 9 million people aged 60 and more (above 24\%). In the years 1989-2016, the number of elderly people grew by nearly 3.7 million, where the greatest increase, i.e., by more than 0.9 million, was in the group of the ones aged between 60 and 64 . The share of people aged over 60 rose by nearly $10 \%$, i.e., from $14.7 \%$ in 1989 to $24.2 \%$ in 2017 . At the same time, the percentage of children and youth decreased by approximately $12 \%$. In the subpopulation of the elderly, the largest group (circa 33\%) is composed of people aged between 60 and 64 [20]. More importantly, within the past 25 years, the number of people in this age spectrum has grown by nearly $50 \%$ [21].

The elderly significantly more often suffers from health problems, frequently resulting in restricted independence. According to the results of the recent count of dwelling population of 2011, nearly 4.7 million people, i.e., over $12 \%$ of the total population of Poland, described their health as unsatisfactory, where the term of "unsatisfactory" includes such health issues as: Disability, chronic disease or conditions restricting the possibility of performing daily activities on a long-term basis [22].

As can be seen, approximately $12 \%$ of society living in flats are confronted with restricted functioning at home. Along with the aging of society, the above-presented situation will escalate. It should also be noted that there are persons only temporarily limited in their functioning such as, regardless of their age, accident casualties, discharged post-operative patients, are temporarily not entirely dextrous.

Due to the fact that the state of health has a major effect on our residential needs, the above-presented elements should be taken into consideration when designing new, not only public, but also residential buildings. In view of the fact that humans spend approximately $12 \mathrm{~h}$ daily at home, places of residence should be adapted to people's needs, where necessary adjustments should be taken into consideration much earlier than upon reaching the retirement age.

\subsection{The Concept of Barrier-Free Universal Design Housing}

Surprisingly, despite its socio-economic benefits, the principles of "universal design" are-as for now-uncommon in the Polish developer market. Taking into consideration aging of society, a progressively longer life expectancy combined with the occurrence of temporary or permanent disabilities, it seems to be the optimal time to introduce the universal design barrier-free flats. The above study aimed to demonstrate that the implementation of the universal design principles at an appropriate design stage does not entail any significant increase in the costs of buildings at the as-built-by-developer state and, at the same time, considerably extends the range of potential buyers.

At first glance, a flat for a senior resident or a disabled person does not differ from a standard flat presently available in the housing market. However, a considerable advantage of a barrier-free flat is the fact that, when buying it, the user does need to worry about the quality of living in the flat after reaching the retirement age. Barrier-free flats do not require any further reconstructions or renovations. It can be stated that the flat "ages" along with its user and adapts to their needs. Once the resident has reached a certain age, it is possible to easily install equipment facilitating everyday living and functioning in the flat, as well as preventing the necessity of changing the place of residence. Flats built in accordance with the universal design principles are free from any movement-related barriers and adapted to the wheelchair, doorways are doorstep-free, and spaces allow for wheelchair maneuverability. The bathroom is "senior-friendly". The walls are prepared for the attachment of 
necessary equipment, and related systems are adapted to meet the needs of the elderly and/or disabled residents. The buildings with barrier-free flats are also characterized by barrier-free surroundings, including access ramps, low curbs, appropriate passageways and lifts, also facilitating the daily life of parents with small children (using prams or pushchairs).

Such flats can be occupied by elderly residents, as well as middle-aged entirely fit persons. With the passage of time and along with the resident's age, because of their versatile nature, these flats can "transform" naturally and inexpensively meeting specific age-related needs as they come into existence. Living in such a flat, a resident can smoothly, and stress-free enter the senior age.

The resident does not become a "prisoner" in their own flat. Wide doors, easy-to-open windows, doorstep-free entrances/doorways and a comfortable bathroom are advantages providing each group of users with more comfortable living.

It is assumed that the area of flats for senior residents should be restricted within the range of $50 \mathrm{~m}^{2}$ to $70 \mathrm{~m}^{2}$. However, it is also recommended to consider the larger multi-generation flats to address situations when one of the elderly parents is disabled without their own flat and in need of a certain degree of care. Another frequently encountered model is a family + a senior family member. Such cases require an additional room and the adaptation of the flat to meet the senior resident's needs. The proposition of building senior residential housing meets the current needs of the Polish society.

\subsection{Sustainable Development in Relation to the Universal Design of Senior Housing as Part of the Silver Industry}

The sustainable development paradigm may be considered with respect to both: (1) The development mechanism (through the prism of real processes) and (2) the concept of policy planning. Sustainable development is regarded as a super long-term concept of human, social, economic space and ecological development focusing at maintaining balance in the biosphere, thus, retaining the natural foundations of the biological and socio-economic growth. It is a concept of broad civilizational perspective, encompassing the results of development in the human, social, economic and environmental dimensions (capitals). The paramount objective (mission) of the sustainable development strategy is to improve the quality of life in its broad sense, while preserving the sustainability of the development capital.

According to the classic definition, there are two integrated pillars of sustainable development [23]:

(1) balancing (integrating) the social, economic and environmental sets of development objectives with the socially accepted value system, and

(2) sustainability of development capitals.

Generally, the development capital comprises the following dimensions: Human, socio-institutional, economic and natural. The human capital consists of the intellectual, innovative, psychomotor, motivational and behavioral potential of particular people. The quality of the human capital is determined by the features of mental and physical disposition (health, knowledge, motivation, creativity and ability to co-operate). Institutionalized and group activities of the human capitals in local and supra-local dimensions constitute the social capital. Whereas, individuals have the human capital at their disposal, the social capital encompasses the totality of connections and the structure of the given community. Therefore, the social (socio-institutional) capital comprises organizational structures that allow for maintenance and development of the human capital, such as economic organizations, government and self-government administrative units, network structures, labor unions, families, non-profit organizations, legal institutions and authorities, political structures, educational institutions, healthcare, etc. The economic capital encompasses both fixed and working capitals. Fixed capital comprises the assets (buildings, constructions, machines, devices, infrastructure and other assets and long-term financial liabilities). The natural (ecological) capital encompasses the resources and the flows of the energy/matter, as well as the physical conditions such as the climatic conditions or the development mechanisms (cycles) of the ecosystems. The ecological resources comprise atmospheric 
gases (including the ozone layer), renewable and non-renewable resources, environmental assimilation capacity, landscape value, biosphere and its food chain, and the carbon, nitrogen and water cycles.

The silver industry growth fulfills the mission of the sustainable development strategy by improving the quality of life and creates sustainability of all dimensions of development capital (Table 5).

Table 5. Silver industry impact on the sustainability of development capital.

\begin{tabular}{cc}
\hline Dimensions of Development Capital & Silver Industry's Impact on Capital Sustainability \\
\hline Human capital & growth of motivational and behavioral potential of senior people \\
\hline Social capital & seniors participation in social life \\
\hline Economic capital & growth of senior-friendly infrastructure (constructions, houses) and services \\
\hline Natural capital & saving resources by implementing senior housing universal design \\
\hline & Source: Results of own research.
\end{tabular}

Implementing the concept of sustainability of development capital is usually considered as the biggest challenge of public policy in the XXI century [24,25]. The scope of the implementation may be described by analyzing the practice applying the main principles of this paradigm (Table 6).

Table 6. Principles of sustainable development in relation to the universal design of senior housing as part of the silver industry.

\begin{tabular}{|c|c|c|c|}
\hline No. & Description & Origin & $\begin{array}{l}\text { Relation to the Universal } \\
\text { Design of Senior Housing } \\
\text { and Silver Industry }\end{array}$ \\
\hline \multicolumn{4}{|c|}{ A. Principles integrating the dimensions of sustainable development } \\
\hline 1 & $\begin{array}{l}\text { Equal access to the environment (interregional, inter- and } \\
\text { intragenerational justice) }\end{array}$ & European Union & +++ \\
\hline 2 & $\begin{array}{l}\text { Environmental capacity (not exceeding the environmental capacity). } \\
\text { Sustainability of the development capital (so-called sensitive and } \\
\text { strong sustainability principle) }\end{array}$ & $\begin{array}{l}\text { European Union, WCN, } \\
\text { ESCP, }\end{array}$ & +- \\
\hline 3 & $\begin{array}{l}\text { Integration of the deals of development. Environment as an } \\
\text { inseparable part of the development strategy and programmed, incl. } \\
\text { living environment }\end{array}$ & AGENDA 21 & ++ \\
\hline \multicolumn{4}{|c|}{ B. Universal recommendations (guidelines) of sustainability } \\
\hline 4 & Legal, technological, ecological effectiveness and economic efficiency & AGENDA 21, WCN, & +++ \\
\hline 5 & $\begin{array}{l}\text { Prevention and prudence. Continuous assessment of the impact on } \\
\text { the environment, recycling and BAT }\end{array}$ & AGENDA 21, EU, & +++ \\
\hline 6 & $\begin{array}{l}\text { High level of: Environmental protection (protection of the natural } \\
\text { capital), biodiversity protection and minimization of resource } \\
\text { consumption, waste production and emission }\end{array}$ & WCN, ESCP, & + \\
\hline 7 & $\begin{array}{l}\text { High level of national heritage protection (anthropogenic capital) } \\
\text { and architecture rehabilitation, maintenance and protection, } \\
\text { including buildings and monuments; territorial attractiveness }\end{array}$ & ESCP & ++ \\
\hline 8 & $\begin{array}{l}\text { High level of human capital protection; elimination of poverty; } \\
\text { quality and social access to education; employment, energy, health } \\
\text { protection, housing, training, transport etc. }\end{array}$ & AGENDA 21, ESCP & +++ \\
\hline 9 & $\begin{array}{l}\text { Regionalization (decentralization) and subsidiarity; exploiting the } \\
\text { local culture and identity of the inhabitants to program the } \\
\text { sustainable development }\end{array}$ & AGENDA 21, EU & +- \\
\hline 10 & $\begin{array}{l}\text { Partnership and social participation; access to information, } \\
\text { participation in the decision making; participation of all sectors of } \\
\text { the local community in the local planning process }\end{array}$ & AGENDA 21, EU, ESCP & + \\
\hline & \multicolumn{3}{|c|}{$\begin{array}{l}\text { Abbreviations: WCN-World Charter for Nature; AGENDA 21-Rio Declaration-Earth Charter, Global Action } \\
\text { Program; EU-the programs of the European Union; ESCP-European Sustainable Cities Platform; Legend: +++ } \\
\text { strong impact; ++ moderate impact; + weak impact; +- neutral; - disadvantageous; Source: Based on: Malik K., } \\
\text { Evaluation of Regional Development Policy: Methods, Contexts and Dimensions of Sustainable Development [24]. }\end{array}$} \\
\hline
\end{tabular}


Universal design of senior housing (UDSH) is the crucial part of the silver industry. Senior housing conditioning by universal design may significantly decrease the costs of improving the senior quality of life, who are to constitute more than $35 \%$ of the future generation (2040). Social justice (intra- and intergenerational) and social integration as fundamental principles of sustainable development are practically implemented by the universal design of senior housing. Therefore, the UDSH generates social cohesion and contributes to human wellbeing and the saving of resources. UDSH not only contributes to the potential growth of GDP, but it also strongly corresponds to all dimensions of sustainable development which is contemporarily the leading paradigm of European Union 2020 Strategy [26]. The EU silver industry is actually the third largest economy in the world behind China and the USA [27].

\section{Conclusions}

Fundamental principles of sustainable development: Social justice (intra- and intergenerational) and social integration are practically implemented in the universal design of senior housing.

At present, the market failure of the construction sector results from one side-the poor demand for building (new) housing, which has been designed to house older population (relatively cheap) and from the other side- the demand for age-friendly house renovations (relatively expensive) acceding the supply of such renovation [5].

The intergenerational market for housing is no longer a efficient mechanism of resource allocation. It is still because the change in demand and supply may generate macroeconomic and social welfare increase.

The reconstruction and adaptation of flats are significantly more expensive and laborious than forward-looking long-term barrier-free design. While implementing the appropriate universal design principles at the architectural design stage, the costs can be reduced by approx. PLN 385 billion, which corresponds to more than 19\% of Poland's GDP (at 2017 prices).

The government intervention should be undertaken to internalize the macroeconomy benefits into the micro calculation level of construction and design companies. The possible ways of this intervention may be considered:

- Public financial support to cover the universal design housing extra cost,

- Introducing minimum national standards-a system of certification to ensure the implementation of consistent design standards for age-friendly houses, such as the UK's Lifetime Homes Standard, - Promoting the UDSH solution in public sector housing construction.

The general instruments of public social policy, mentioned above, require an in-depth strategic analysis in the field of the silver industry development. The research of the social and economic benefits of UDSH should be expanded to age-friendly environment solutions in the city and community levels.

Primary construction of barrier-free flats, apart from meeting the needs of the elderly and disabled ones, could also aid the daily functioning in a case of temporary disability, since the need of freedom and independence is important at every stage of adult life. Combining the needs of the young individuals with those of the elderly could help to make developer's offer more flexible, economic effective and social-needs oriented.

Author Contributions: K.M. and E.M. designed the article and research; K.M. and E.M. conducted the desk research and calculated the data; K.M. and E.M. wrote the paper.

Funding: This research received no external funding.

Conflicts of Interest: The authors declare no conflict of interest. 


\section{References}

1. Stupar, A.; Mihajlov, V.; Lalovic, K.; Colic, R.; Petrovic, F. Participative placemaking in Serbia: The use of the limitless GIS application in increasing the sustainability of universal urban design. Sustainability 2019, 11, 5459. [CrossRef]

2. Borowczyk, J. Sustainable urban development: spatial analyses as novel tools for planning a universally designed city. Sustainability 2018, 10, 1407. [CrossRef]

3. Beltratti, A.; Chichilnisky, G.; Heal, G. Sustainable Growth and the Green Golden Rule. In The Economics of Sustainable Development; Cambridge University Press: Cambridge, UK, 1995.

4. The Principles of Universal Design (Version 2.0-4/1/97). Available online: https://projects.ncsu.edu/ncsu/ design/cud/about_ud/udprinciplestext.htm (accessed on 1 November 2019).

5. European RDI Policies for the Construction Sector in the Silver Economy. Available online: https://ec.europa. eu/research/innovation-union/pdf/active-healthy-ageing/ectp.pdf (accessed on 29 November 2019).

6. Cieśla, A.; Cieśla, J.P. Features of a Secure Senior House. Available online: https://www.pzh.gov.pl/wpcontent/uploads/2018/11/Cechy-bezpiecznego-mieszkania-seniora.pdf (accessed on 1 November 2019).

7. Polish Central Statistical Office. Living Conditions in Poland. Available online: https: //stat.gov.pl/obszary-tematyczne/warunki-zycia/dochody-wydatki-i-warunki-zycia-ludnosci/warunkimieszkaniowe-w-polsce-w-2017-roku,28,1.html (accessed on 1 November 2019).

8. Polish Central Statistical Office. Population. Size and Structure and Vital Statistics in Poland by Territorial Division in 2018. As of June 30. Available online: https://stat.gov.pl/en/topics/population/population/ population-size-and-structure-and-vital-statistics-in-poland-territorial-divison-in-2018-as-of-june-30,3, 24.html (accessed on 1 November 2019).

9. Polish Central Statistical Office: Forecast of Residing Population for Poland for the Years 2015 through 2050. Available online: https://stat.gov.pl/obszary-tematyczne/ludnosc/prognoza-ludnosci/prognoza-ludnoscirezydujacej-dla-polski-na-lata-2015-2050,8,1.html (accessed on 29 November 2019).

10. Katalogi Nakładów Rzeczowych. Katalogi Nakładów Rzeczowych (KNR) Do Programu Rodos; Wydawnictwo Budowlane Koprin: Koszalin, Poland, 2017.

11. BKI Baukosteninformationszentrum. BKI Baukosten Gebäude + Bauelemente + Positionen Neubau 2017 - Kombi Teil 1-3: Statistische Kostenkennwerte Gebäude, Positionen und Bauelemente; Verlagsgesellschaft Rudolf Müller Gmbh \&co. Kg: Cologne, Germany, 2017; ISBN 978-3481036379.

12. Bugajska, B.; Iwański, R.; Szarota, Z. Where does the old age dwell? Space-architecture-home. Polish Soc. Gerontol. J. 2018, 1-2, 43-57. [CrossRef]

13. Held, M.; Anders, C.H.; Kelka, J.U.; Müller, A. Barrierefreies Bauen im Kostenvergleich Teil I: Eine Analyse Notwendiger Mehrausgaben Gegenüber Konventionellen Bauweisen von TERRAGON WOHNBAU. Available online: https://www.terragon-ag.de/wp-content/uploads/2019/04/TERRAGONStudie-Kostenvergleich-Barrierefreies-Bauen.pdf (accessed on 1 November 2019).

14. Opieka dla Seniora 2018 (Senior People Care 2018). Available online: https://polskatimes.pl/opieka-dlaseniora-2018-ile-to-kosztuje-jak-zalatwic-pobyt/ar/13239805 (accessed on 29 November 2019).

15. Eurostat Household Budget Survey. Available online: https://ec.europa.eu/eurostat/web/microdata/ household-budget-survey (accessed on 19 November 2019).

16. Barrett, P.; Barrett, L.; Davies, F. Achieving a step change in the optimal sensory design of buildings for users at all life-stages. Build. Environ. 2013, 67, 97-104. [CrossRef]

17. Peine, A.; Rollwagen, I.; Neven, L. The rise of the "innosumer"-Rethinking older technology users. Technol. Forecast. Soc. Chang. 2014, 82, 199-214. [CrossRef]

18. A memorandum by the Central Statistical Office of Poland Presented at a session of the Parliamentary Committee for Senior Policy and Containing Information by the Minister of Health on the Effect of Demographic Changes and the Aging of the Organization of the Health Care System and the National Health Scheme (on 19 February 2016). Available online: https://stat.gov.pl/download/gfx/portalinformacyjny/pl/ defaultaktualnosci/5468/24/1/1/ludnosc_w_wieku_60._struktura_demograficzna_i_zdrowie.pdf. (accessed on 29 November 2019).

19. Polish Central Statistical Office. Population Projection 2014-2050. Available online: https://stat. gov.pl/en/topics/population/population-projection/population-projection-2014-2050,2,5.html (accessed on 1 November 2019). 
20. Polish Central Statistical Office. The Demographic Situation of the Elderly and the Consequences of the Aging of the Polish Population in the Light of the Forecast for 2014-2050; Polish Central Statistical Office: Warsaw, Poland, 2014.

21. Pearce, D.; Barbier, E.; Markandya, A. Sustainable Development: Economics and Environment in the Third World; Routledge: Abingdon, UK, 1990.

22. Sachs, J.D. The Age of Sustainable Development; Columbia University Press: New York, NY, USA, 2015; pp. 162-312. ISBN 9780231173155.

23. Hawksworth, J.; Tiwari, A. The World in 2050. The Accelerating Shift of Global Economic Power: Challenges and Opportunities; PwC: London, UK, 2011; pp. 30-32. ISBN 150128-085441-DC-OS.

24. Malik, K. Evaluation of Regional Development Policy: Methods, Contexts and Dimensions of Sustainable Development; Studia KPZK PAN: Warszawa, Poland, 2011; ISBN 978-83-62736-49-2.

25. Helne, T.; Hirvilammi, T. Wellbeing and sustainability: A relational approach. Sustain. Dev. 2015, 23, 167-175. [CrossRef]

26. European Commission. Europe 2020: A Strategy for Smart, Sustainable and Inclusive Growth. COM (2010) 2020 Final. Available online: http://eur-lex.europa.eu/LexUriServ/LexUriServ.do?uri=COM:2010:2020:FIN: EN:PDF (accessed on 1 November 2019).

27. The Silver Economy: An Overview of the European Commission's Activities. Available online: https://silvereconomyforum.eu/wp-content/uploads/2019/07/Silver-Economy-Brochure.pdf (accessed on 1 November 2019).

(C) 2019 by the authors. Licensee MDPI, Basel, Switzerland. This article is an open access article distributed under the terms and conditions of the Creative Commons Attribution (CC BY) license (http://creativecommons.org/licenses/by/4.0/). 